\title{
Effects of Titanium Dioxide Nanoparticles on the Hprt Gene Mutations in V79 Hamster Cells
}

\author{
Alena Kazimirova ${ }^{1, *}$, Naouale El Yamani ${ }^{2}$, Laura Rubio ${ }^{3}{ }^{-0}$, Alba García-Rodríguez ${ }^{4}$, \\ Magdalena Barancokova ${ }^{1}$, Ricard Marcos 4,5 and Maria Dusinska ${ }^{2, *(D)}$ \\ 1 Department of Biology, Faculty of Medicine, Slovak Medical University, 83303 Bratislava, Slovakia; \\ magdalena.barancokova@szu.sk \\ 2 Health Effects Laboratory, Department of Environmental Chemistry, \\ NILU-Norwegian Institute for Air Research, N-2027 Kjeller, Norway; ney@nilu.no \\ 3 Nanobiology Laboratory, Department of Natural and Exact Sciences, \\ Pontificia Universidad Católica Madre y Maestra, PUCMM, \\ 80677 Santiago de los Caballeros, Dominican Republic; 1.rubio@ce.pucmm.edu.do \\ 4 Department of Genetics and Microbiology, Faculty of Biosciences, Universitat Autònoma de Barcelona, \\ 08193 Cerdanyola del Vallès (Barcelona), Spain; albagr.garcia@gmail.com (A.G.-R.); \\ ricard.marcos@uab.es (R.M.) \\ 5 Consortium for Biomedical Research in Epidemiology and Public Health (CIBERESP), \\ Carlos III Institute of Health, 28029 Madrid, Spain \\ * Correspondence: alena.kazimirova@szu.sk (A.K.); mdu@nilu.no (M.D.)
}

Received: 31 January 2020; Accepted: 28 February 2020; Published: 5 March 2020

\begin{abstract}
The genotoxicity of anatase/rutile $\mathrm{TiO}_{2}$ nanoparticles $\left(\mathrm{TiO}_{2} \mathrm{NPs}, \mathrm{NM} 105\right.$ at 3, 15 and $75 \mu \mathrm{g} / \mathrm{cm}^{2}$ ) was assessed with the mammalian in-vitro Hypoxanthine guanine phosphoribosyl transferase (Hprt) gene mutation test in Chinese hamster lung (V79) fibroblasts after $24 \mathrm{~h}$ exposure. Two dispersion procedures giving different size distribution and dispersion stability were used to investigate whether the effects of $\mathrm{TiO}_{2} \mathrm{NPs}$ depend on the state of agglomeration. $\mathrm{TiO}_{2} \mathrm{NPs}_{\mathrm{N}}$ were fully characterised in the previous European FP7 projects NanoTEST and NanoREG2. Uptake of $\mathrm{TiO}_{2}$ NPs was measured by transmission electron microscopy (TEM). $\mathrm{TiO}_{2} \mathrm{NPs}$ were found in cytoplasmic vesicles, as well as close to the nucleus. The internalisation of $\mathrm{TiO}_{2} \mathrm{NPs}$ did not depend on the state of agglomeration and dispersion used. The cytotoxicity of $\mathrm{TiO}_{2} \mathrm{NPs}_{2}$ was measured by determining both the relative growth activity (RGA) and the plating efficiency (PE). There were no substantial effects of exposure time (24, 48 and $72 \mathrm{~h}$ ), although a tendency to lower RGA at longer exposure was observed. No significant difference in PE values and no increases in the Hprt gene mutant frequency were found in exposed relative to unexposed cultures in spite of evidence of uptake of NPs by cells.
\end{abstract}

Keywords: titanium dioxide nanoparticles; V79 cells; genotoxicity; Hprt

\section{Introduction}

Nano-sized or ultrafine titanium dioxide particles $\left(\mathrm{TiO}_{2} \mathrm{NPs}\right)$ are among the most widely used nanomaterials. $\mathrm{TiO}_{2}$ is a poorly soluble particulate material with numerous applications such as food colorant or white pigment in the production of paints, paper, plastics, ink and welding rod-coating material. $\mathrm{TiO}_{2} \mathrm{NPs}(<100 \mathrm{~nm})$ are increasingly used in other industrial products, such as cosmetics, skin care products (in sunscreens, as an ultraviolet blocking agent), toothpaste, and pharmaceuticals [1-4]. It can even be used as a food additive, for example to whiten skimmed milk [5]. Therefore, potential widespread exposure may occur during manufacturing and use [6].

Whether $\mathrm{TiO}_{2} \mathrm{NPs}$ represent any hazard to humans is a question addressed by various regulatory agencies. Genotoxicity studies of $\mathrm{TiO}_{2} \mathrm{NPs}$ have been widely performed detecting different types 
of DNA damage such as strand breaks and various DNA lesions (using mostly the comet assay), gene mutations in bacteria and in mammalian cells, as well as chromosomal damage representing possible clastogenic or aneugenic effects. However, in-vivo and in-vitro studies have reported conflicting results; some indicate that $\mathrm{TiO}_{2} \mathrm{NPs}$ are genotoxic [6-9], whereas others give negative results [8,10-12]. This inconsistency is related to the different particle types used, with different NP sizes and physico-chemical properties, NP dispersion and exposure conditions, as well as to the use of different cell culture media, cellular models, and test methods [13-16]. Most of genotoxic effects are seen in cells derived from the respiratory, and the circulatory systems. Where internal exposure of the lungs can occur, there is a possibility that $\mathrm{TiO}_{2} \mathrm{NP}$ may exert genotoxic effects, most probably through secondary mechanisms (e.g. oxidative stress); however, direct interaction with the genetic material cannot be excluded. Overall, the studies indicating that $\mathrm{TiO}_{2} \mathrm{NPs}$ are genotoxic outweigh the studies that state otherwise. According to that, $\mathrm{TiO}_{2} \mathrm{NPs}$ can be treated as potentially hazardous compounds [5] consistent with the fact that $\mathrm{TiO}_{2}$ itself is classified as a class $2 \mathrm{~B}$ carcinogen [17].

The mammalian gene mutation tests belong to the set of assays recommended by the regulatory bodies and, in nanomaterial genotoxicity testing, they are preferred since the Ames test is not suitable due to the size of bacteria (comparable with NPs themselves) and the fact that the bacterial wall limits significantly the uptake of NPs $[14,18]$. The most commonly used target genes for measuring the induction of mutations in mammalian cells are the thymidine kinase $(T k)$ and the hypoxanthine guanine phosphoribosyl transpherase (Hprt) genes. Specifically, the Hprt mutation assay has already been successfully applied to the evaluation of different nanomaterials [6,18-21].

With regard to studies using $\mathrm{TiO}_{2} \mathrm{NPs}$ to induce Hprt mutants, previous studies have already been reported, where positive effects were observed in the WIL2-NS human B-cell lymphoblastoid cell line (24 h exposure of $130 \mu \mathrm{g} / \mathrm{mL}$ UF- $\mathrm{TiO}_{2}$ ) [6], and in V79-4 hamster cells ( $2 \mathrm{~h}$ of short-term treatment of 20 and $100 \mu \mathrm{g} / \mathrm{mL}$ anatase $\mathrm{TiO}_{2} \mathrm{NPs}$ [7]. Interestingly, negative results were obtained with anatase $\mathrm{TiO}_{2} \mathrm{NPs}(10-40 \mu \mathrm{g} / \mathrm{mL})$ in a long-term (60 days) exposure experiment. In that case, Chinese hamster

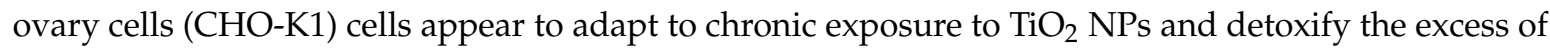
reactive oxygen species (ROS), possibly through an up-regulation of super oxide dismutase (SOD), in addition to reducing particle uptake [10].

In this context, the aim of our work is to investigate whether $\mathrm{TiO}_{2} \mathrm{NPs}$ induce mutagenic effect in the Hprt gene, and whether this effect depends on the dispersion procedure used, e.g. on different states of agglomeration.

\section{Material and Methods}

\subsection{Cells}

V79-4 adherent hamster cells isolated from the lung of a normal Chinese hamster (male), were purchased from European Collection of Authenticated Cell Cultures (ECACC, catalogue number 86041102). Cells were cultured in Dulbecco's minimal essential medium (DMEM) D6046 (Sigma, Steinheim, Germany) supplemented with $10 \%$ (v/v) heat-inactivated fetal bovine serum (FBS, Gibco, Grand Island, NY, USA) and $1 \%(\mathrm{v} / \mathrm{v})$ penicillin-streptomycin (Gibco) at $37^{\circ} \mathrm{C}$ in a $5 \% \mathrm{CO}_{2}$ humidified atmosphere. Cells were thawed and sub-cultured 2-4 times before use in the experiments, at an initial density of $2 \times 10^{5}$ cells $/ \mathrm{mL}$ in vented T-75 $\mathrm{cm}^{2}$ flasks. Cultures were maintained with density not exceeding $1 \times 10^{6}$ cells $/ \mathrm{mL}$ at the time of passage. Cells were seeded $24 \mathrm{~h}$ to reach $50-70 \%$ confluence before exposure to test substance. Trypan blue assay was used to check cell viability after trypsinization of cells.

\subsection{Nanoparticle Characterization, Dispersion and Cell Exposure}

$\mathrm{TiO}_{2} \mathrm{NP}$ (NM-105), an anatase/rutile nanopowder of nominal size $21 \mathrm{~nm}(15-60 \mathrm{~nm})$, was received from the EU Joint Research Centre (Ispra, Italy). It was manufactured by Evonik (Essen, Germany), 
and marketed as Aeroxide $\mathrm{TiO}_{2} \mathrm{P}-25 . \mathrm{TiO}_{2}$ NPs were fully characterised in previous EU projects [13,22], and results are summarised in Table 1.

Table 1. Summary of primary physical and chemical properties of the used $\mathrm{TiO}_{2} \mathrm{NPs} \mathrm{NM}-105$ [13].

\begin{tabular}{cc}
\hline Type of Characteristics & Properties of NM-105 \\
\hline Phase & White ultra-fine powder \\
Shape of particles & Irregular/ellipsoidal \\
Particle size $(\mathrm{nm})$ & $15-60$ \\
Crystal structure & Anatase/Rutile in ratio of $70: 30$ or $80: 20$ \\
Surface area $\left(\mathrm{m}^{2} / \mathrm{g}\right)$ & 61 \\
Pore volume $(\mathrm{mL} / \mathrm{g})$ & 0.13 \\
Zeta-potential at $\mathrm{pH} 7(\mathrm{mV})$ & -30.2 \\
Chemical composition of particles & $\mathrm{Ti}, \mathrm{O}$ \\
Ti purity of particles & $>99 \%$ \\
Surface chemistry & Uncoated \\
Impurities of concern & Co $(920 \mathrm{ppm}), \mathrm{Fe}(16 \mathrm{ppm})$ \\
\hline
\end{tabular}

For the treatment of cells we used $\mathrm{TiO}_{2}$ NP dispersed by two different procedures, either with or without serum in stock solution. This can permit investigations on how the state of aggregation/agglomeration and stability of the dispersion could influence $\mathrm{TiO}_{2} \mathrm{NP}$ cytotoxicity and genotoxicity.

\section{Dispersion Procedure DP1}

Stock suspensions of $\mathrm{TiO}_{2} \mathrm{NPs}$ at $5 \mathrm{mg} / \mathrm{mL}$ were freshly prepared for each experiment, using the dispersion procedure DP1 developed as part of the FP7 project NanoTEST. For $1 \mathrm{~mL}$ of stock suspension, $5 \mathrm{mg}$ of $\mathrm{TiO}_{2}$ NPs mixed with $1 \mathrm{~mL}$ of $10 \%$ fetal bovine serum (FBS, Gibco) in PBS (phosphate buffered saline) in a glass tube was sonicated using an ultrasonic probe sonicator (Labsonic, Sartorius, Gottingen Germany) at $100 \mathrm{~W}$ for $15 \mathrm{~min}$ on ice/water. This suspension was added to cell culture medium. Serial dilutions were made in cell culture medium to obtain the full range of NP suspensions, from 3 to $75 \mu \mathrm{g} / \mathrm{cm}^{2}$, which were then immediately added to cells.

\section{Dispersion Procedure DP2}

In DP2, $20 \mathrm{mg}$ of $\mathrm{TiO}_{2} \mathrm{NPs}$ was suspended in $10 \mathrm{~mL}$ of culture medium with $15 \mathrm{mM}$ HEPES buffer and without FBS (the procedure developed at University Paris Diderot France [13]). The suspension was sonicated using the ultrasonic probe sonicator at $60 \mathrm{~W}$ for $3 \mathrm{~min}$ on ice/water, vortexed for $10 \mathrm{~s}$, and within $2 \mathrm{~min}$ of sonication-aliquoted and stored at $-20^{\circ} \mathrm{C}$ for further use. $\mathrm{TiO}_{2} \mathrm{NP}$ suspension aliquots were thawed just before use, vortexed for $10 \mathrm{~s}$, sonicated at $60 \mathrm{~W}$ for $1 \mathrm{~min}$ on ice/water and added to cell culture medium. Serial dilutions were made in cell culture medium to obtain the full range of $\mathrm{TiO}_{2} \mathrm{NP}$ suspensions from 3 to $75 \mu \mathrm{g} / \mathrm{cm}^{2}$, which were then immediately added to cells.

\subsection{Extrinsic Properties of $\mathrm{TiO}_{2} \mathrm{NPS}$}

Particle size, size distribution, state of agglomeration and stability of $\mathrm{TiO}_{2} \mathrm{NPs}$, both in stock solution as well as in culture medium, were characterized by Nanoparticle Tracking Analysis (NTA) using NanoSight NS 500 (NanoSight Limited, Netherhampton, Salisbury, UK). Table 2 shows size, agglomeration state and stability in culture medium measured by Dynamic Light Scattering DLS [22]. 
Table 2. Average hydrodynamic diameters determined, by Dynamic Light Scattering (DLS), of the obtained $\mathrm{TiO}_{2}$ NPs stock dispersions [22].

\begin{tabular}{ccc}
\hline Medium & TiO $_{2}$ Stock Dispersion DP1 & TiO $_{2}$ Stock Dispersion DP2 \\
\hline DMEM $+10 \%$ FBS & Bimodal distribution, $112( \pm 20) \mathrm{nm}$ and $296( \pm 55) \mathrm{nm}$ & $752( \pm 397) \mathrm{nm}$ \\
\hline Size stability after $48 \mathrm{~h}$ & Stable $\sim 2$ days $125( \pm 27) \mathrm{nm}$ and $366( \pm 65) \mathrm{nm}$ & Large Agglomerates \\
\hline
\end{tabular}

DMEM-Dulbecco's minimal essential medium; FBS—fetal bovine serum.

\subsection{Cellular Uptake}

Cellular uptake of $\mathrm{TiO}_{2} \mathrm{NPs}$ was measured by transmission electron microscopy (TEM). V79-4 cells were grown on 6-well plates at a density of $1.75 \times 10^{5}$ cells/well. Cells were exposed to $\mathrm{TiO}_{2} \mathrm{NPs}$ dispersed according to DP1 and DP2 $\left(3,10,30 \mu \mathrm{g} / \mathrm{cm}^{2}\right)$ for $24 \mathrm{~h}$. At the end of the exposure time, cells were centrifuged, fixed in 2.5\% (v/v) glutaraldehyde (EM grade, Merck, Darmstadt, Germany) and 2\% (w/v) paraformaldehyde (EMS, Hatfield, PA, USA) in $0.1 \mathrm{M}$ cacodylate buffer at pH 7.4 (PB, Sigma-Aldrich, Steinheim, Germany), and processed following conventional procedures, as previously described [23]. Samples were first post-fixed with osmium tetroxide, dehydrated in acetone, later embedded in Epon, and finally polymerized at $60{ }^{\circ} \mathrm{C}$, and cut with an ultramicrotome Leica EM UC6 using a diamond knife and mounted on copper grids. Before image acquisition, sections were stained using uranyl acetate and Reynolds lead-citrate solutions. All images were examined using a JEOL 1400 (JEOL LTC, Tokyo, Japan) TEM at $120 \mathrm{kV}$ equipped with a CCD GATAN ES1000W Erlangshen camera.

\subsection{Relative Growth Activity (RGA)}

RGA measurements are based on cell proliferation activity of the cells during a period of treatment or after treatment with the tested compound. Cells were seeded at concentration $1 \times 10^{5}$ cells per well on 12-well plates in $2 \mathrm{~mL}$ culture medium and were kept for $24 \mathrm{~h}$ under standard conditions at $37^{\circ} \mathrm{C}$ in a $5 \% \mathrm{CO}_{2}$ humidified atmosphere. Cells were then exposed to different concentrations (ranging from 0.12 to $75 \mu \mathrm{g} / \mathrm{cm}^{2}$ ) of $\mathrm{TiO}_{2} \mathrm{NPs}$ lasting for 24,48 , and $72 \mathrm{~h}$. Untreated cells, just with cell culture medium, were used as a negative control and hydrogen peroxide $\left(\mathrm{H}_{2} \mathrm{O}_{2}, 100 \mu \mathrm{M}, 5 \mathrm{~min}\right.$ in PBS) was used as a positive control. Just after exposure, medium was removed from the culture and cells were washed with PBS, trypsinized, and re-suspended in $1 \mathrm{~mL}$ of medium. Finally, $10 \mu \mathrm{L}$ of the final cell suspension was mixed with $10 \mu \mathrm{L}$ of $0.4 \%$ trypan blue (Life Technologies, OR, USA) to determine the percentage of viable cells (unstained) and stained cells with damaged membranes. This determination was carried out using a Countess ${ }^{\mathrm{TM}}$ Automated Cell Counter (Invitrogen). RGA was calculated as already published [24].

\subsection{Plating Efficiency (PE)}

To determine the potential cytotoxic effects of the treatment, after $24 \mathrm{~h}$ exposure of V79-4 cells to $\mathrm{TiO}_{2}$ NPs, they were washed, trypsinized and counted, as described above. After that, 50 cells per well were inoculated in 6-well plates (for each concentration tested one plate was used) and incubated at $37^{\circ} \mathrm{C}$ for 7 days. Untreated cells, just with cell culture medium, were used as a negative control. Finally, cells were stained by using $1 \%$ methylene blue (Sigma) and the number of resulting colonies was counted manually. PE values were calculated according to the formula:

$$
P E(\%)=\frac{\text { number of colonies in exposed cultures }}{\text { number of colonies in unexposed cultures }} \times 100 \%
$$

\subsection{Hprt Mammalian Gene Mutation Assay}

The mammalian in vitro Hprt gene mutation test was performed according to the OECD Guidelines for the Testing of Chemicals 476 [25]. V79-4 cells were cultured in $100 \mathrm{~mm}$ diameter Petri dishes; $1 \times 10^{6}$ cells were inoculated per dish in $10 \mathrm{~mL}$ medium in duplicate for each concentration, and incubated at 
$37^{\circ} \mathrm{C}$. On the following day, the cells were exposed to $\mathrm{TiO}_{2} \mathrm{NPs}$ for $24 \mathrm{~h}$, at concentrations from 3 to $75 \mu \mathrm{g} / \mathrm{cm}^{2}$.

Untreated cells cultured in medium for $24 \mathrm{~h}$ were used as negative control and cells treated for $3 \mathrm{~h}$ with $0.1 \mathrm{mM}$ methyl methanesulfonate (MMS; Sigma), served as the positive control.

After exposure, the medium was removed, and cells were washed, trypsinized and re-suspended in $2 \mathrm{~mL}$ of medium. They were then seeded in $100 \mathrm{~mm}$ diameter Petri dishes at $3 \times 10^{5}$ cells/dish, 3 dishes per concentration. Cells were grown for 8 days, during which they were subcultured three times; duplicate samples were taken at 6 and 8 days after treatment for analysis of mutant frequencies. To detect mutants, cells were inoculated in $100 \mathrm{~mm}$ diameter Petri dishes at $2 \times 10^{5}$ cells/dish, 5 dishes per sample giving a total of $10^{6}$ cells per sample and grown in medium containing 6-thioguanine (Sigma) at $5 \mu \mathrm{g} / \mathrm{mL}$ for 10 days to form colonies. 6-Thioguanine is an analogue of guanine, toxic to cells with functioning Hprt gene, and so only $\mathrm{Hprt}^{-}$cells survive. Mutant colonies were counted manually after staining with $1 \%$ methylene blue; only colonies with at least 50 cells were counted.

For each of the two harvests ( 6 and 8 day duplicate samples), the frequency of surviving cells was assessed using the PE assay, as described above. Treated and untreated cells were seeded in 6-well plates at 50 cells per well, 1 plate per concentration, and incubated for 7 days at $37^{\circ} \mathrm{C}$ to form colonies. Cell viability was calculated for each mutant harvest on the basis of the number of colonies as a percentage of the number of inoculated cells. The mutant frequency was determined as previously described [24].

\subsection{Statistical Analysis}

One way analysis of variance ANOVA test was used, followed by Dunnett's multiple comparison test for the post hoc analysis. Prism 7.0 (GraphPad Software, San Diego, CA, USA) and Microsoft Excel 2013 were used for statistics and mathematical analysis. Differences with $P<0.05$ were considered statistically significant.

\section{Results}

\section{1. $\mathrm{TiO}_{2}$ Characterization, Extrinsic Properties}

As NPs change their properties depending on the surrounding environment, we also measured extrinsic properties of $\mathrm{TiO}_{2} \mathrm{NPs}$. We also aimed to identify whether size and stability of dispersion can influence the potential effect. The size distribution, state of agglomeration and stability of the tested $\mathrm{TiO}_{2} \mathrm{NPs}$ were analysed in culture medium before the treatment and immediately after the treatment (times 0 and $24 \mathrm{~h}$ ) by using NTA measured by NanoSight NS 500. The average size of the $\mathrm{TiO}_{2}$ NPs in DMEM at time 0, was $228 \pm 3.2 \mathrm{~nm}$, and $184 \pm 3.5 \mathrm{~nm}$, for DP1 and DP2, respectively. After $24 \mathrm{~h}$, the mean size of $\mathrm{TiO}_{2} \mathrm{NPs}$ prepared by DP1 was $154.1 \pm 6.7$, while $\mathrm{TiO}_{2} \mathrm{NPs}$ prepared by DP2 had an average size of $217 \pm 3.6$ showing relatively stable dispersion for both DPs, as showed in Figure 1. After $24 \mathrm{~h}$, the $\mathrm{TiO}_{2}$ NPs dispersion DP2 was similar to time $0 \mathrm{~h}$, but when we compare the concentration of particles per $\mathrm{mL}$ between time 0 and $24 \mathrm{~h}$, a decrease in the concentration was observed. Extrinsic characteristics of size, size distribution, and the level of agglomeration/ aggregation of NPs in dispersions measured by DLS are described in Table 2. 

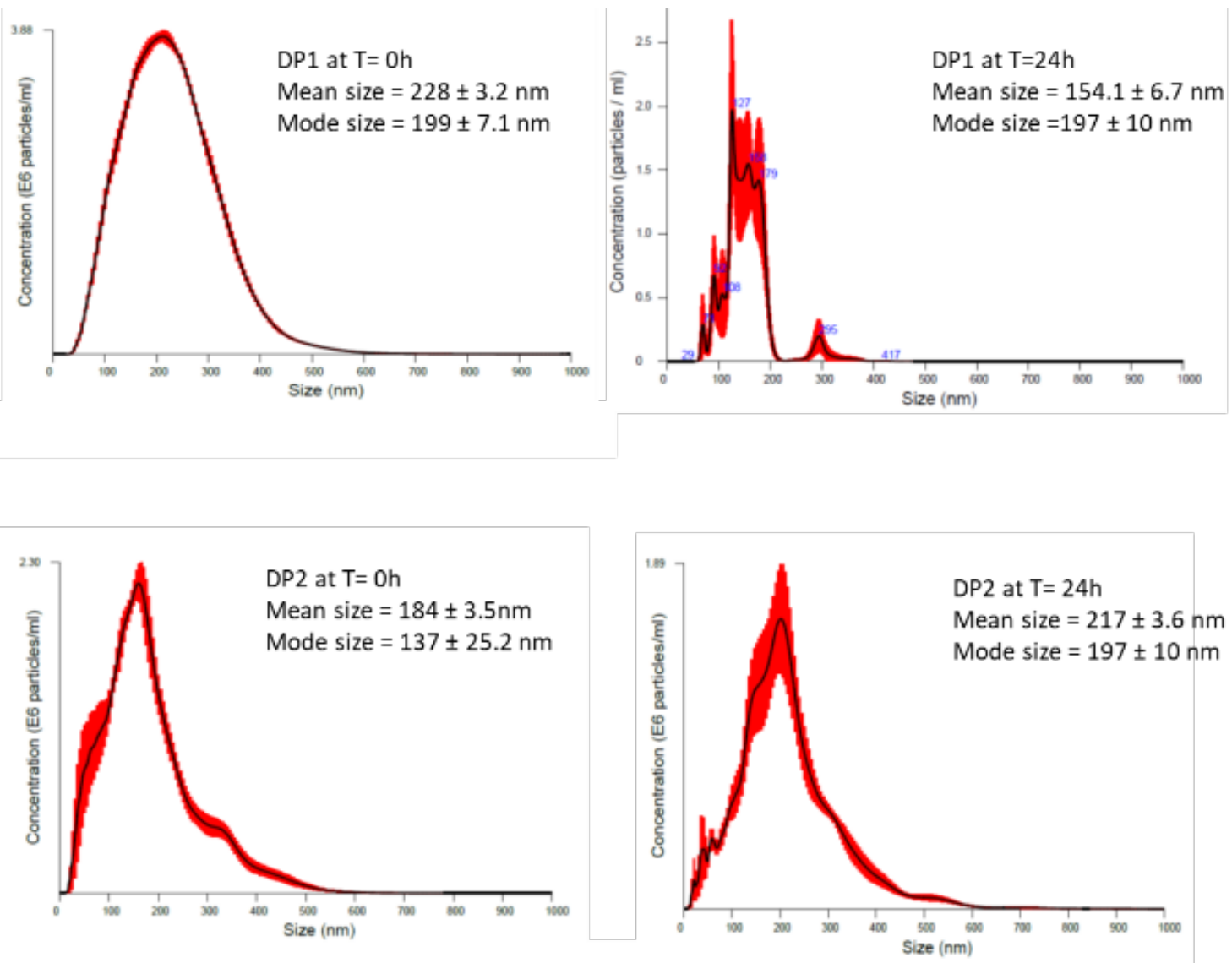

Figure 1. Particle size distribution obtained by (NTA) of $\mathrm{TiO}_{2} \mathrm{NPs}_{\text {sing }}$ the two proposed dispersion procedures (DP1 and DP2) in culture medium at 0 and $24 \mathrm{~h}$. The black line is the mean distribution and the red filling represent standard errors between captured videos.

\subsection{Uptake of $\mathrm{TiO}_{2} \mathrm{NPs}$ Measured by the TEM}

The potential cell uptake of $\mathrm{TiO}_{2}$ NPs was investigated in V79-4 cells after exposures to 3, 10 and $30 \mu \mathrm{g} / \mathrm{cm}^{2}$ of the $\mathrm{TiO}_{2} \mathrm{NPs}$ prepared using both dispersion procedures. Figure 2 shows that after $24 \mathrm{~h}$ of $\mathrm{TiO}_{2} \mathrm{NPs}$ exposure they were taken up mostly as agglomerates and these were found in cytoplasm and vesicles. Agglomerates of $\mathrm{TiO}_{2} \mathrm{NPs}$ were also detected in contact with the cell nucleus even when low concentrations of $\mathrm{TiO}_{2} \mathrm{NPs}$ were used. It seems that the uptake of $\mathrm{TiO}_{2} \mathrm{NPs}$ did not depend on the used dispersion since there was no difference in uptake of $\mathrm{TiO}_{2} \mathrm{NPs}$, whichever dispersion procedure was used.

\subsection{Cytotoxic Effect of $\mathrm{TiO}_{2}$ NPs on V79-4 Cells}

An important endpoint for measuring the effect of NPs on cells is cytotoxicity. In our study the cytotoxicity of $\mathrm{TiO}_{2}$ NPs in V79-4 cells was measured by determining both the RGA and the PE values. RGA measures cytotoxicity in population of cells, while the PE gives information on individual cell toxicity. RGA values were determined as the ratio between the number of living cells, after exposures lasting for 24, 48 and $72 \mathrm{~h}$, versus the number of living cells in the unexposed cultures. Figure 3 shows that, in general, $\mathrm{TiO}_{2} \mathrm{NPs}$ exposures were not excessively toxic with rather more marked effects when DP1 was used. In addition, no significant effects of exposure time were seen, although there was a tendency to observe higher effects at longer exposure times.

The PE values were determined as the ratio of the number of colonies observed in the exposed cultures versus those observed in the unexposed cultures. Exposure lasted for $24 \mathrm{~h}$ and colonies were counted after 7 days of growth. As shown in Figure 4, no significant differences were observed 
between the negative control and each of the concentrations used $\left(3,15\right.$ and $\left.75 \mu \mathrm{g} / \mathrm{cm}^{2}\right)$. In addition, no differences in PE values were observed between the two dispersion procedures.

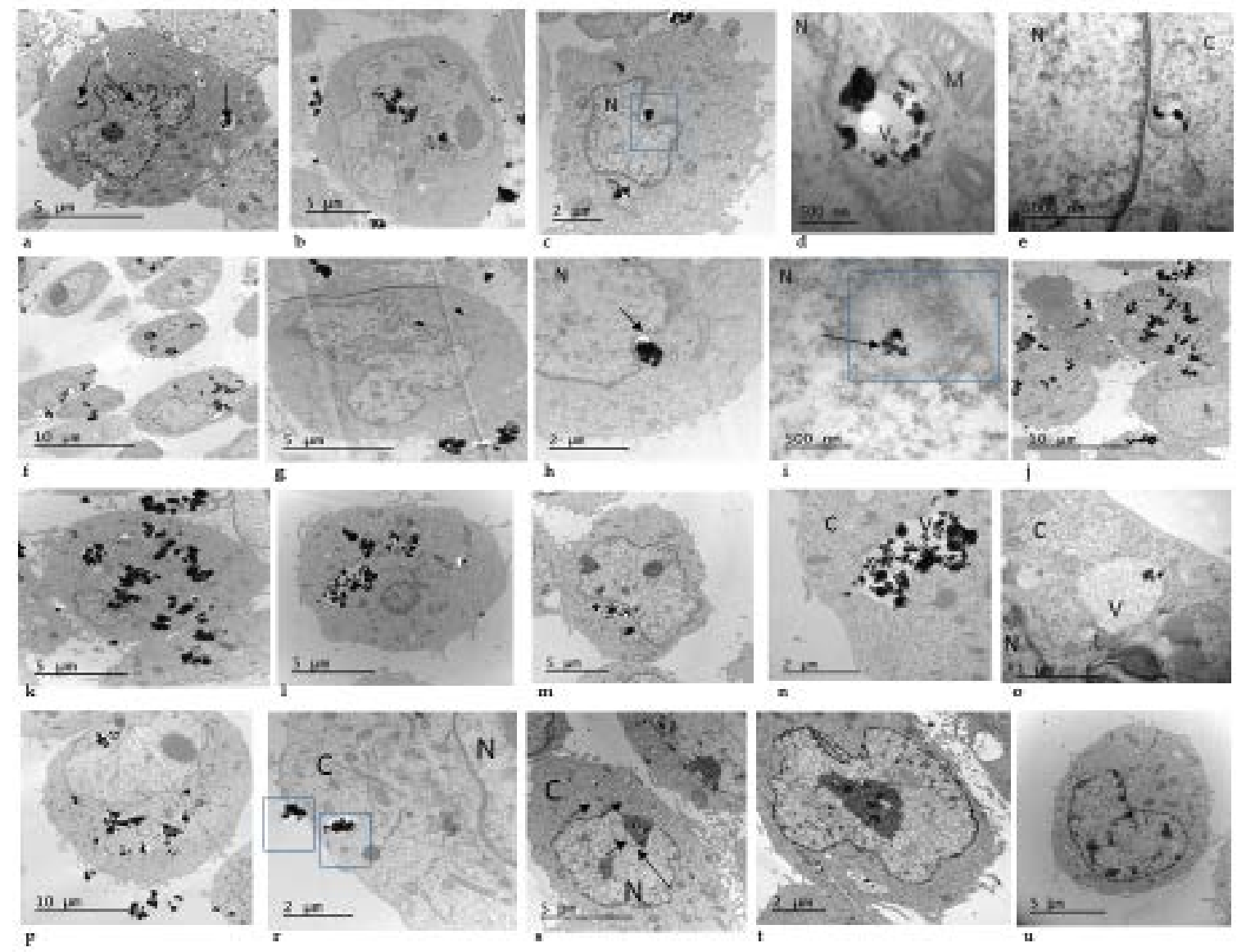

Figure 2. Representative transmission electron microscopy (TEM) figures of titanium dioxide $\mathrm{TiO}_{2}$ NM105 uptake by Chinese hamster lung fibroblast (V79-4) cells exposed to 3, 10 and $30 \mu \mathrm{g} / \mathrm{cm}^{2}$ of $\mathrm{TiO}_{2}$ NPs dispersed according to dispersion procedure 1 (DP1) and dispersion procedure 2 (DP2). DP1 $3 \mu \mathrm{g} / \mathrm{cm}^{2}$ (a-e), DP1 $10 \mu \mathrm{g} / \mathrm{cm}^{2}$ (f-i), DP1 $30 \mu \mathrm{g} / \mathrm{cm}^{2}$ (j,k), DP2 $3 \mu \mathrm{g} / \mathrm{cm}^{2}$ (1-o), DP2 $10 \mu \mathrm{g} / \mathrm{cm}^{2}$ $(\mathbf{p}-\mathbf{r})$, DP2 $30 \mu \mathrm{g} / \mathrm{cm}^{2}(\mathbf{s}, \mathbf{t})$, Negative control untreated V79-4 cells $(\mathbf{u}) . \mathrm{N}=$ nucleus; $\mathrm{C}=$ cytoplasm; $\mathrm{V}=$ vesicle, $\mathrm{M}=$ mitochondrion.

\subsection{Mammalian Hprt Gene Mutation Assay, the Effect After $\mathrm{TiO}_{2} \mathrm{NPs}$ Exposure}

Genotoxicity is one of the most crucial effects that should be investigated in assessing safety of chemicals including NPs and it covers several genotoxicity endpoints, namely gene mutations, and structural and numerical chromosome aberrations. In our study we assessed the mutation potential of $\mathrm{TiO}_{2}$ NPs in V79-4 cells in two different experiments for each harvest point. As observed in Figure 5, there were no significant differences between the negative control and any of the three $(3,15$ and $75 \mu \mathrm{g} / \mathrm{cm}^{2}$ ) concentrations used. This observed lack of mutagenic effects was independent of the dispersion used. In contrast, the positive control (MMS, $0.1 \mathrm{mM}, 3 \mathrm{~h}$ ) showed a clear induction of Hprt mutants, supporting the validity of the assay, and confirming the lack of mutagenic potential of the $\mathrm{TiO}_{2} \mathrm{NPs}$, at least under our experimental conditions. 


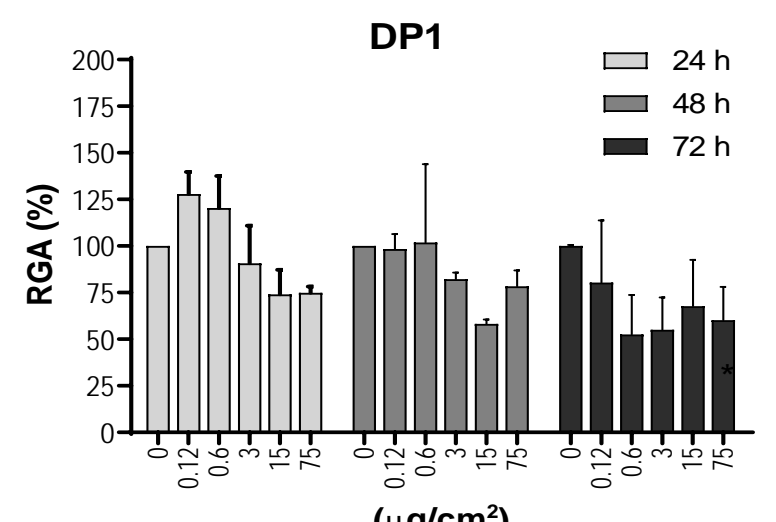

$\left(\mu \mathrm{g} / \mathrm{cm}^{2}\right)$

(a)

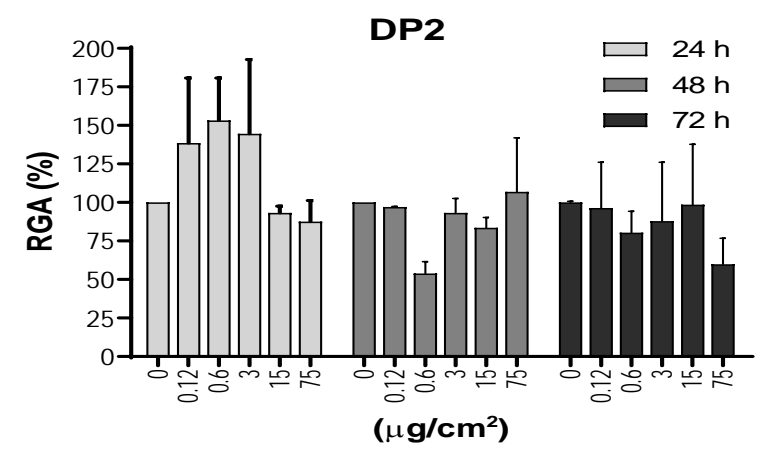

(b)

Figure 3. (a) and (b). Cytotoxic effects measured as the relative growth activity (RGA \%) on V79-4 cells exposed to $\mathrm{TiO}_{2}$ NPs prepared using the two dispersion procedures (DP1 and DP2). Cells were treated with 5 concentrations $\left(\mu \mathrm{g} / \mathrm{cm}^{2}\right)$ of $\mathrm{TiO}_{2} \mathrm{NPs}$ for 24,48 and $72 \mathrm{~h}$, and the cell numbers were counted at each time point immediately, following trypan blue staining. There were no statistical significances between exposed and unexposed cultures. Cytotoxicity of MMS was not been observed (RGA =70\%). Data are expressed as the means \pm SEM of two parallel experiments, according to the used procedures.

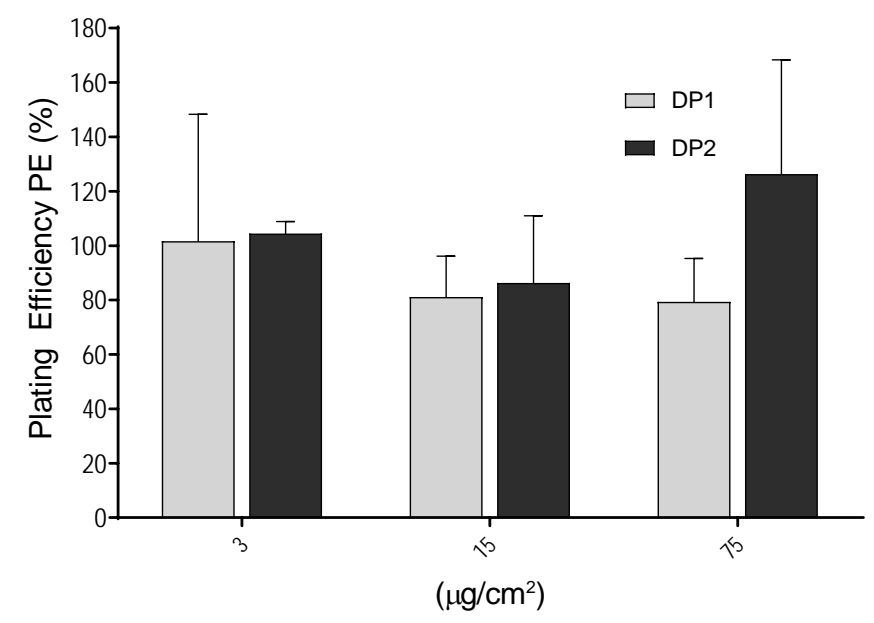

Figure 4. Cytotoxic effects of $\mathrm{TiO}_{2} \mathrm{NPs}$ measured by the plating efficiency (PE \%) in V79-4 cells. Bars represent cytotoxicity relative to $100 \%$ of untreated cells Data are expressed as the means \pm SEM of two parallel seedings for plating efficiency, according to the used procedure. No statistical significances between exposed and unexposed cultures were observed. 


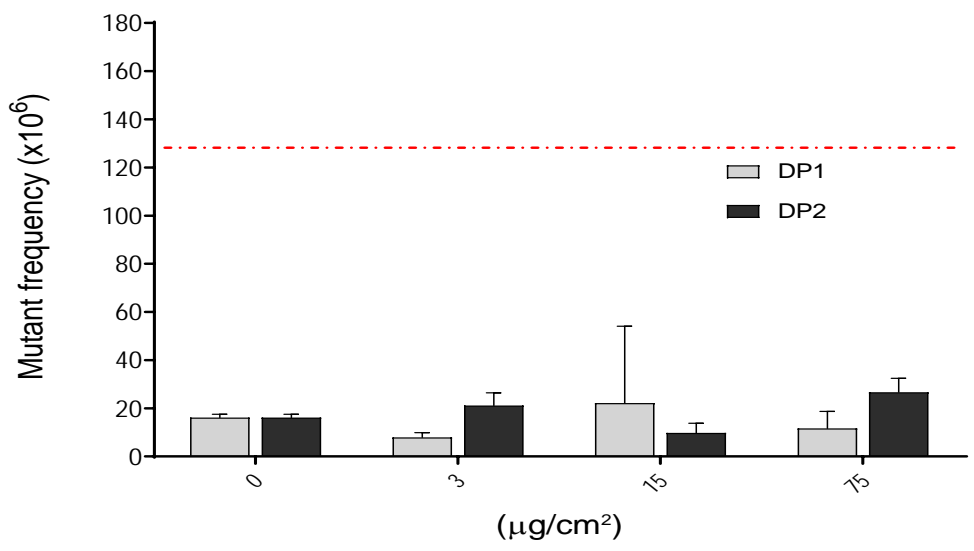

Figure 5. Induction of Hprt gene mutants after the exposure of V79-4 cells to different concentrations of $\mathrm{TiO}_{2}$ NPs for $24 \mathrm{~h}$. There were no statistical significances between exposed and unexposed cultures. Hprt gene mutant frequency in treated cells with positive control MMS $(0.1 \mathrm{mM}, 3 \mathrm{~h})$, which gave 131.6 $\pm 2.30 \mathrm{Hprt}$ gene mutants. This value is indicated as a red-dashed line. Data are expressed as the means \pm SEM of two parallel seedings for mutation frequency MF1 and MF2, according to the used procedure.

\section{Discussion}

In-vitro toxicology data, based on well-designed experiments are required for risk assessment strategies designed for the testing of engineered nanomaterials. Until now, while in-vitro tests have been successfully applied in nanotoxicology studies, reference and quality standards are not always included: determination of physico-chemical properties, a range of appropriate controls (including stabilizer controls) and representative cell models, among other aspects, are crucially important.

Furthermore, physical processes in the preparation of the nanomaterials to be tested, such as dissolution, aggregation and sedimentation must be taken into consideration to better understand the mechanism of ENM toxicity [26]. In our study, the effects of $\mathrm{TiO}_{2} \mathrm{NPs}$ were compared using two different DPs: one with serum in the stock solution and one without, in order to investigate whether the dispersion procedure and dispersion components could influence NP cytotoxicity and genotoxicity. In addition, we have evaluated the genotoxic potency by detecting their ability to induce gene mutations at the Hprt locus. It should be noted that the evaluation of the genotoxic potential of $\mathrm{TiO}_{2} \mathrm{NPs}$ has been the subject of different reviews [16,27-30].

The Hprt gene mutation assay has been widely used in human biomonitoring and this target seems to be a valuable biomarker to determine the genotoxic/carcinogenic risk of exposures [31]. Accordingly, the mammalian gene mutation test is considered a surrogate in vitro marker for use in cancer risk assessment, together with the micronucleus assay. The use of the Hprt forward gene mutation assay allows the quantification of a wide set of genetic changes such as base substitutions, amplifications, or small deletions. This assay has already been used to determine the mutagenicity of $\mathrm{TiO}_{2}$ NPs in different types of cells $[6,7,10,32]$. Thus, in cultured WIL2-NS cells, a human B-cell lymphoblastoid cell line, ultrafine $\mathrm{TiO}_{2}$ particles ( $<100 \mathrm{~nm}$ in diameter) induced approximately 2.5 -fold increases in the mutation frequency, in addition to significant toxicity [6]. However, negative results were obtained when $\mathrm{TiO}_{2}$ NPs were evaluated in Chinese hamster ovary (CHO-K1) cells subject to chronic exposures of up to 60 days [10]. In such cells no cytotoxic effects were apparent using the XTT (2,3-bis(2-methoxy-4-nitro-5-sulfophenyl)22H-tetrazolium-5-caboxyanilide), trypan-blue exclusion, and colony-forming assays for viability and, in addition, no variations in the frequency of Hprt mutations were reported. Finally, the Hprt assay has also been used in V79 cells to determine the mutagenic potential of $\mathrm{TiO}_{2} \mathrm{NPs}$, showing a clear dose-dependent effect [7,32]. This disparity in the obtained results would support the view that there are many factors affecting the outcome when the genotoxicity of NPs in general, and $\mathrm{TiO}_{2} \mathrm{NPs}$ in particular, is evaluated. It is important to point out that, in spite of the reported contradictory data, $\mathrm{TiO}_{2} \mathrm{NPs}$ are well taken up by mammalian cells, 
including V79 cells. In this case, our positive uptake findings have been confirmed by a recent study using flow cytometric analysis and TEM in the same cell line [32]. In this study TEM micrographs showed the internalization (confirmed by SEM/EDX analysis) of $\mathrm{TiO}_{2} \mathrm{NPs}$ in the cytoplasm inducing ultra-structural changes such as swollen mitochondria and nuclear membrane disruption.

The ability of $\mathrm{TiO}_{2}$ NPs to produce gene mutants has also been tested using gene targets other than the Hprt gene. Thus, the mouse lymphoma assay targeting the Tk gene was used to determine the mutagenicity of $\mathrm{TiO}_{2}$ NPs, with negative results [33]. These negative results were obtained independently of the presence/absence of the microsomal S9 fraction in the culture medium.

As previously indicated, the Hprt assay has also been used to evaluate the genotoxic potential of other nanomaterials. Thus, by using silver nanomaterials it was shown that such NPs were mutagenic in V79-4 cells and, interestingly, this effect depended on their size [26]. On the other hand, amorphous silica NPs were evaluated for the detection of both Hprt mutants and ROS production in V79 cells, with negative results [34]. Furthermore, when multi wall carbon nanotubes were tested in the dose-range of 0.12 to $12 \mu \mathrm{g} / \mathrm{cm}^{2}$, significant cellular uptake was observed by using transmission electron microscopy. In addition, a clear concentration-dependent increase in the induction of Hprt mutants was seen together with a significant increase in the levels of intracellular reactive oxygen species [20]. Finally, this gene mutation assay has also been used to detect the mutagenic potential of nickel oxide NPs. In that case, a small but statistically significant increase in the frequency of Hprt mutations was observed for NiO NPs but only at one of the different tested doses [21].

From our results it appears that the dispersion procedure is not a factor modulating the genotoxicity of $\mathrm{TiO}_{2} \mathrm{NPs}$. Thus, there were no significant increases in the Hprt gene mutation frequency when the two different methods in our study were applied. These results would agree with those reported using the same $\mathrm{TiO}_{2} \mathrm{NPs}$, where no increases in the frequency of micronuclei in TK6 cells, rat bone marrow erythrocytes, or human lymphocytes were observed following three different dispersion procedures [35]. In the same study, using the comet assay, $\mathrm{TiO}_{2} \mathrm{NPs}$ dispersed in a stable, non-agglomerated state were able to induce DNA strand breaks in human white blood cells, although no increases in levels of DNA oxidation were seen. The overall conclusion of that study is that NPs in an agglomerated state were unable to cause DNA damage. The observed differences in the results obtained with the different assays can be consequences of the differences in the mechanisms underlying the genotoxic effects detected by the different assays [35]. The dispersion procedure not only can affect genotoxicity but also toxicity. The levels of agglomeration/aggregation of NPs and their size distribution depends on the dispersion procedure, and on the use of serum in stock solution. In our case, DP1 using FBS gave a relatively stable dispersion of $\mathrm{TiO}_{2} \mathrm{NPs}$, while with the second procedure DP2, rapid formation of $\mathrm{TiO}_{2} \mathrm{NP}$ agglomerates occurred in the testing medium as measured by DLS, as well as by TEM [13]. Our results show also a discrepancy in measurement of size distribution and stability of dispersion in exposure medium between NTA and DLS measurements, implying that DLS gives a more realistic measure of extrinsic properties of NPs, compared with NTA.

Independently of the results obtained in this study, a procedure giving more stable dispersion should be preferred, so as to avoid false negative data that may be caused by the uptake difficulties associated with big agglomerations/aggregations.

Author Contributions: Conceptualization: M.D., A.K., methodology: A.K., L.R., N.E.Y., A.G.-R., M.B., NTA: N.E.Y., TEM analysis: A.G.-R., R.M., statistical analysis: N.E.Y., writing—original draft preparation, A.K., N.E.Y.; writing-review and editing, A.K., M.D., R.M., N.E.Y., funding acquisition: M.D. All authors have read and agree to the published version of the manuscript.

Funding: A. Kazimirova was supported by QualityNano Transnational Access fellowship. This investigation has been supported by the EC FP7 NANoREG (Grant Agreement NMP4-LA-2013-310584), EC FP7 QualityNano (grant agreement INFRA-2010-1.131), by the Research Council of Norway, the project NorNANoREG (239199/O70) and by RiskGONE, contract no H2020-NMBP-TO-IND-2018-814425.

Acknowledgments: We thank Iren Elisabeth Sturtzel for their excellent help with experiments. Authors also thank Andrew Collins for critical reading and language corrections. 
Conflicts of Interest: The authors report no conflicts of interest. The authors alone are responsible for the content and writing of the paper.

\section{References}

1. Baan, R.; Straif, K.; Grosse, Y.; Secretan, B.; El Ghissassi, F.; Cogliano, V. Carcinogenicity of carbon black, titanium dioxide, and talc. Lancet Oncol. 2006, 7, 295-296. [CrossRef]

2. Weir, A.; Westerhoff, P.; Fabricius, L.; von Goetz, N. Titanium dioxide nanoparticles in food and personal care products. Environ. Sci. Technol. 2013, 46, 2242-2250. [CrossRef] [PubMed]

3. Chen, X.X.; Cheng, B.; Yang, Y.X.; Cao, A.N.; Liu, J.H.; Du, L.J.; Liu, Y.F.; Zhao, Y.L.; Wang, H.F. Characterization and preliminary toxicity assay of nano-titaniumdioxide additive in sugar-coated chewing gum. Small 2013, 9, 1765-1774. [CrossRef] [PubMed]

4. Winkler, H.C.; Notter, T.; Meyer, U.; Naegeli, H. Critical review of the safety assessment of titanium dioxide additives in food. J. Nanobiotechnol. 2018, 16, 51. [CrossRef]

5. Shi, H.; Magaye, R.; Castranova, V.; Zhao, Z. Titanium dioxide nanoparticles: a review of current toxicological data. Part. Fibre Toxicol. 2013, 10, 15. [CrossRef]

6. Wang, J.J.; Sanderson, B.J.; Wang, H. Cyto- and genotoxicity of ultrafine $\mathrm{TiO}_{2}$ particles in cultured human lymphoblastoid cells. Mutat. Res. 2007, 628, 99-106. [CrossRef]

7. Chen, Z.; Wang, Y.; Ba, T.; Li, Y.; Pu, J.; Chen, T.; Song, Y.; Gu, Y.; Qian, Q.; Yang, J.; et al. Genotoxic evaluation of titanium dioxide nanoparticles in vivo and in vitro. Toxicol. Lett. 2014, 226, 314-319. [CrossRef]

8. Tavares, A.M.; Louro, H.; Antunes, S.; Quarré, S.; Simar, S.; Temmerman, P.J.D.; Verleysen, E.; Mast, J.; Jensen, K.A.; Norppa, H.; et al. Genotoxicity evaluation of nanosized titanium dioxide, synthetic amorphous silica and multi-walled carbon nanotubes in human lymphocytes. Toxicol. In Vitro 2013, 28, 60-69. [CrossRef]

9. El Yamani, N.; Collins, A.R.; Rundén-Pran, E.; Fjellsbo, L.M.; Shaposhnikov, S.; Zienolddiny, S.; Dusinska, M. In vitro genotoxicity testing of four reference metal nanomaterials, titanium dioxide, zinc oxide, cerium oxide and silver: towards reliable hazard assessment. Mutagenesis 2017, 32, 117-126. [CrossRef]

10. Wang, S.; Hunter, L.A.; Arslan, Z.; Wilkerson, M.G.; Wickliffe, J.K. Chronic exposure to nanosized anatase titanium dioxide is not cyto- or genotoxic to Chinese hamster ovary cells. Environ. Mol. Mutagen. 2011, 52, 614-622. [CrossRef]

11. Guichard, Y.; Schmit, J.; Darne, C.; Gaté, L.; Goutet, M.; Rousset, D.; Rastoix, O.; Wrobel, R.; Witschger, O.; Martin, A.; et al. Cytotoxicity and genotoxicity of nanosized and microsized titanium dioxide and iron oxide particles in Syrian hamster embryo cells. Ann. Occup. Hyg. 2012, 56, 631-644. [PubMed]

12. Hamzeh, M.; Sunahara, G.I. In vitro cytotoxicity and genotoxicity studies of titanium dioxide $\left(\mathrm{TiO}_{2}\right)$ nanoparticles in Chinese hamster lung fibroblast cells. Toxicol. In Vitro 2013, 27, 864-873. [CrossRef]

13. Magdolenova, Z.; Bilanicova, D.; Pojana, G.; Fjellsbø, L.M.; Hudecova, A.; Hasplova, K.; Marcomini, A.; Dusinska, M. Impact of agglomeration and different dispersions of titanium dioxide nanoparticles on the human related in vitro cytotoxicity and genotoxicity. J. Environ. Monit. 2012, 14, 455. [CrossRef] [PubMed]

14. Magdolenova, Z.; Collins, A.; Kumar, A.; Dhawan, A.; Stone, V.; Dusinska, M. Mechanisms of genotoxicity. A review of in vitro and in vivo studies with engineered nanoparticles. Nanotoxicology 2014, 8, 233-278. [CrossRef] [PubMed]

15. Prasad, R.Y.; Wallace, K.; Daniel, K.M.; Tennant, A.H.; Zucker, R.M.; Strickland, J.; Dreher, K.; Kligerman, A.D.; Blackman, C.F.; Demarini, D.M. Effect of treatment media on the agglomeration of titanium dioxide nanoparticles: impact on genotoxicity, cellular interaction, and cell cycle. ACS Nano 2013, 7, 1929-1942. [CrossRef] [PubMed]

16. Charles, S.; Jomini, S.; Fessard, V.; Bigorgne-Vizade, E.; Rousselle, C.; Michel, C. Assessment of the in vitro genotoxicity of $\mathrm{TiO}_{2}$ nanoparticles in a regulatory context. Nanotoxicology 2018, 12, 357-374. [CrossRef]

17. IARC Working Group on the Evaluation of Carcinogenic. Risks to humans: carbon black, titanium dioxide, and talc. IARC Monogr. Eval. Carcinog. Risks Hum. 2010, 93, 1.

18. Doak, S.H.; Manshian, B.; Jenkins, G.J.S.; Singh, N. In vitro genotoxicity testing strategy for nanomaterials and the adaptation of current OECD guidelines. Mutat. Res. 2012, 745, 104-111. [CrossRef]

19. Asakura, M.; Sasaki, T.; Sugiyama, T.; Takaya, M.; Koda, S.; Nagano, K.; Arito, H.; Fukushima, S. Genotoxicity and cytotoxicity of multi-wall carbon nanotubes in cultured Chinese hamster lung cells in comparison with chrysotile A fibers. J. Occup. Health 2010, 52, 155-166. [CrossRef] 
20. Rubio, L.; El Yamani, N.; Kazimirova, A.; Dusinska, M.; Marcos, R. Multi-walled carbon nanotubes (NM401) induce ROS-mediated HPRT mutations in Chinese hamster lung fibroblasts. Environ. Res. 2016, 146, 185-190. [CrossRef]

21. Åkerlund, E.; Cappellini, F.; Di Bucchianico, S.; Islam, S.; Skoglund, S.; Derr, R.; Odnevall Wallinder, I.; Hendriks, G.; Karlsson, H.L. Genotoxic and mutagenic properties of $\mathrm{Ni}$ and $\mathrm{NiO}$ nanoparticles investigated by comet assay, y-H2AX staining, Hprt mutation assay and ToxTracker reporter cell lines. Environ. Mol. Mutagen. 2018, 59, 211-222. [PubMed]

22. Dusinska, M.; Boland, S.; Saunders, M.; Juillerat-Jeanneret, L.; Tran, L.; Pojana, G.; Marcomini, A.; Volkovova, K.; Tulinska, J.; Knudsen, L.E.; et al. Towards an alternative testing strategy for nanomaterials used in nanomedicine: Lessons from NanoTEST. Nanotoxicology 2015, 7, 118-132. [CrossRef] [PubMed]

23. Annangi, B.; Bach, J.; Vales, G.; Rubio, L.; Marcos, R.; Hernández, A. Long-term exposures to low doses of cobalt nanoparticles induce cell transformation enhanced by oxidative damage. Nanotoxicology 2015, 9, 138-147. [CrossRef] [PubMed]

24. Huk, A.; Izak-Nau, E.; El Yamani, N.; Uggerud, H.; Vadset, M.; Zasonska, B.; Duschl, A.; Dusinska, M. Impact of nanosilver on various DNA lesions and HPRT gene mutations -effects of charge and surface coating. Part. Fibre Toxicol. 2015, 12, 25. [CrossRef]

25. OECD Test, No. 476: In Vitro Mammalian Cell Gene Mutation Tests Using the Hprt and xprt Genes. In OECD Guidelines for the Testing of Chemicals, Section 4: Health Effects; OECD: Paris, France, 2016; Available online: https:/www.oecd-ilibrary.org/docserver/9789264264809-en.pdf?expires=1582877457\& $\mathrm{id}=\mathrm{id} \&$ accname $=$ guest\&checksum=AF948B418DF0BC20B908E85A06F87F69 (accessed on 17 August 2016).

26. Huk, A.; Izak-Nau, E.; Reidy, B.; Boyles, M.; Duschl, A.; Lynch, I.; Dušinska, M. Is the toxic potential of nanosilver dependent on its size? Part. Fibre Toxicol. 2014, 11, 65. [CrossRef]

27. Chen, T.; Yan, J.; Li, Y. Genotoxicity of titanium dioxide nanoparticles. J. Food Drug Anal. 2014, $22,95-104$. [CrossRef]

28. Zhang, X.; Li, W.; Yang, Z. Toxicology of nanosized titanium dioxide: an update. Arch. Toxicol. 2015, 89, 2207-2217. [CrossRef]

29. Shakeel, M.; Jabeen, F.; Shabbir, S.; Asghar, M.S.; Khan, M.S.; Chaudhry, A.S. Toxicity of nano-titanium dioxide $\left(\mathrm{TiO}_{2}-\mathrm{NP}\right)$ through various routes of exposure: a review. Biol. Trace Elem. Res. 2016, 172, 1-36. [CrossRef]

30. Møller, P.; Jensen, D.M.; Wils, R.S.; Andersen, M.H.G.; Danielsen, P.H.; Roursgaard, M. Assessment of evidence for nanosized titanium dioxide-generated DNA strand breaks and oxidatively damaged DNA in cells and animal models. Nanotoxicology 2017, 11, 1237-1256. [CrossRef]

31. Albertini, R.J. HPRT mutations in humans: biomarkers for mechanistic studies. Mutat. Res. 2001, 489, 1-16. [CrossRef]

32. Jain, A.K.; Senapati, V.A.; Singh, D.; Dubey, K.; Maurya, R.; Pandey, A.K. Impact of anatase titanium dioxide nanoparticles on mutagenic and genotoxic response in Chinese hamster lung fibroblast cells (V-79): The role of cellular uptake. Food Chem. Toxicol. 2017, 105, 127-139. [CrossRef] [PubMed]

33. Du, X.; Gao, S.; Hong, L.; Zheng, X.; Zhou, Q.; Wu, J. Genotoxicity evaluation of titanium dioxide nanoparticles using the mouse lymphoma assay and the Ames test. Mutat. Res. Genet. Toxicol. Environ. Mutagen. 2019, 838, 22-27. [CrossRef] [PubMed]

34. Guichard, Y.; Fontana, C.; Chavinier, E.; Terzetti, F.; Gaté, L.; Binet, S.; Darne, C. Cytotoxic and genotoxic evaluation of different synthetic amorphous silica nanomaterials in the V79 cell line. Toxicol. Ind. Health. 2015, 32, 1639-1650. [CrossRef] [PubMed]

35. Kazimirova, A.; Barancokova, M.; Staruchova, M.; Drlickova, M.; Volkovova, K.; Dusinska, M. Titanium dioxide nanoparticles tested for genotoxicity with the comet and micronucleus assays in vitro, ex vivo and in vivo. Mutat. Res. 2019, 843, 57-65. [CrossRef] [PubMed]

(C) 2020 by the authors. Licensee MDPI, Basel, Switzerland. This article is an open access article distributed under the terms and conditions of the Creative Commons Attribution (CC BY) license (http://creativecommons.org/licenses/by/4.0/). 